DOI: https://doi.org/10.32841/2413-2675/2019-41-8

Tymoshenko Ihor

PhD in Economics, Associate Professor

Economics and International Economic Relations Chair,

Poltava State Agrarian Academy

\title{
SOCIAL ENTREPRENEURSHIP IN THE GLOBAL DIMENSION
}

\section{СОЦІАЛЬНЕ ПІДПРИЄМНИЦТВО У ГЛОБАЛЬНОМУ ВИМІРІ}

Summary. The article highlights the features of social entrepreneurship as a mechanism of interaction between social values and innovative business technologies, aimed at eliminating the issues of socially vulnerable groups of population, due to society's inability to effectively solve them by the traditional ways of a market economy and state support. It examines the functioning of social entrepreneurship not only in developed North American and European countries, where it already has an established tradition, but also in those where it is just beginning to emerge (Latin America, Southeast Asia and Africa). Basing on a comparative analysis of the regional development of social entrepreneurship, it demonstrates the differences between the American and European model. It was revealed that the development of social entrepreneurship depends not only on the current institutional environment, but also on the national conditions in which this type of activity is formed. The peculiarities of legislative and state support of social entrepreneurship in different regions of the world are also investigated, the factors, contributing to the popularity of its practices are determined.

Keywords: social entrepreneurship, American and European models, social innovations, organizational and legal forms, investment funds.

Problem statement. Social entrepreneurship is a relatively new topic in the theory of entrepreneurship. An active discussion about it, mainly in the Western academic community, began around the 1980s, when the need to think of a new form of economic activity and a new way of combining resources, as well as in their theoretical justification arose. In scientific literature, social entrepreneurship is considered a mechanism of interaction between social values and innovative business technologies, aimed at eliminating the issues of socially unprotected categories of people in conditions of society's inability to effectively solve them by the traditional methods of market economy and state support. The develop- ment of social entrepreneurship in different regions of the world is uneven and has a national specificity, due to both - the institutional environment and historical conditions in which this type of activity was formed. The actuality of the topic is determined by the existence of acute social problems in Ukraine, which requires the search for new tools and regulatory mechanisms of their urgent solution and social stability. The research on foreign experience of social entrepreneurship can become a guide for a national strategy of its development.

Research and publications analysis. The issue of social entrepreneurship has been a subject of scientific research since the 1980s 1990s. Motivation for social entrepreneurship and its effectiveness in solving social problems, the features of European and American models of social entrepreneurship development, are reflected in publications of J. Austin, H. Stevenson, J. Wei-Skillern [1], M.J. Christie, B. Honing [2], I. Marti [3], J.A. Kerlin [5; 10], J. Mair, O. Schoen [12], J. Defourni, M. Nissens [6], etc. The forming of social entrepreneurship in Latin America, Southeast Asia and Africa is highlighted by J. Santos [13], M. Capistrano, J. Robinson [14], G. Sesan [17], etc.

The study of social entrepreneurship in Ukraine is fragmentary and still in the process of formation. Separate aspects of this issue are being investigated by such national scientists as I. Bereziak, Z. Halushka, O. Kireieva, I. Mazur, O. Nabatova, O. Poliakova, A. Svynchuk, O. Sotula, V. Udodova, etc., the works of which are aimed at structuring the scientific knowledge of functions, properties and evaluation of social entrepreneurship and the prospects of its further development. 
Highlighting previously unresolved parts of a common issue. The novelty of the social enterprise as a specific type of organization caused ambiguity of views on its essence, and, consequently, the presence of different concepts of support for its development. Existing scientific works do not provide a comprehensive analysis of the various practices and forms of social entrepreneurship in countries with different levels of social and economic development has not yet been carried out, which actualizes the research in this area.

Purpose of the article is to summarize the tendencies of social entrepreneurship development in the modern global socio-economic system, defining the main factors that influence its formation, revealing the national specificity of social enterprises in international practice.

Main research material outline. The emergence of social entrepreneurship (SE) researchers explain by the presence of «market failures in the production of public goods», caused by the instability of global economy and inability of the state to meet the growing social needs of its population [1, p. 5]. Lack of budgetary resources has forced governments to abandon the social security monopoly and delegate certain functions to nonprofit and private service providers. Such approach to the implementation of social policy, on the one hand requires the adoption of innovative decisions aimed at enhancing the effectiveness of social investment, on the other hand - increasing reliance on business and civil society structures. In most developed countries, the reduction of public social costs is accompanied by the implementing of compensation mechanisms, which can prevent the decrease of the achieved social level of the population. As practice shows, social entrepreneurship is an effective tool for targeted social assistance [2, p. 3].

Acting as an intermediary in the field of social services, SE is characterized by the number of specific features: social impact - targeted at solving or mitigating specific social problems; innovativeness - by applying creative and, often, unique methods that allow to create a brand new product or a new model of its promotion; prevalence - the rapid spread of ideas and expansion of the range of activities; entrepreneurial approach, financial stability and self-suffi- ciency, which enables to solve social problems due to own activity. According J. Mayr and I. Marti (scientists from the University of Navarra), - social entrepreneurship is not a charity, but a business, capable of generating income even in a difficult economic situation [3, p. 12]. According to Eric Ries, the successful implementation of a business project with the help of social entrepreneurship requires a social startup, based on the development of innovative goods or services in a creative way [4, p. 118].

Scientists differ European and American models of social entrepreneurship, associated with the peculiarities of national development. The emergence of SE in Western Europe was influenced by the crisis of social security system and the rise in unemployment in the 1970 's. In response, specialized organizations, the activities of which were aimed at meeting the needs of the most vulnerable groups of population, began to emerge. The development of social enterprises in the United States was facilitated by a reduction in state funding of charitable and nonprofit organizations, which participated in federal programs against poverty. To compensate the outflow of funds, they had to start a commerce activity. So, according to J. Kerlin, social entrepreneurship in Europe appeared at the intersection of civil society and the public sector and in the United States - the civil society and the private sector. [5, p. 259]. In regard to this, European and American studies refer different entities to social enterprises, although they acknowledge the commonality of their social purpose.

In most European countries, various NGOs, cooperative and mutual organizations (societies) have become the basis for social entrepreneurship. This fact contributed to fixing the legal status of social enterprises as «social cooperatives». Unlike traditional cooperative organizations, the activity of social cooperatives is aimed at servicing socially vulnerable groups of population and integrating them into the labor market. Legally defined areas in which social enterprises usually operate are: social security, health care, education and professional development, environmental protection, historical heritage preservation, social tourism, cultural services, etc. [6, p. 39]. 
A special kind of SE legal model (different from the continental one) has been developed in the UK. Government "Social Enterprise: A strategy for Success» program implemented a special organizational form - community interest company (a company acting in the interests of the local community). A new type of social enterprise was created for socio-economic rehabilitation of depressed areas and social groups living there. According to the British legislation, the performance of these companies is estimated by market indicators, thus at least 50\% of their income should be obtained through selling goods and services. [7, p. 57].

State initiatives of the EU countries to promote the development of social entrepreneurship are quite diverse and include creating of organizational, administrative and financial conditions at the legislative level, extensive infrastructure support from local authorities, targeted social programs and business projects, etc. Social enterprises in the UK (which are closer to the US model) receive support from municipal organizations and guaranteed participation in government social procurement.

The American model of social entrepreneurship is based on the values of private initiative, charity and independence of civil society from the state, and does not require establishing any special bodies or mechanisms for its financing. Social enterprises are generated by both - the business environment and nonprofit organizations [6, p. 43]. According to the Roberts Enterprise Development Fund, cited by Kim Alter in his work, social enterprise is a venture capital entity, created to mitigate a social issue or compensate the market failures, which functions on the basis of financial discipline, innovation and private-sector business practices [8, p. 11]. Such definition aims to separate the new form of socially-oriented business from nonprofit organizations, the status of which is essentially characterized by «nonprofitability», because of their belonging to the nonprofit «third sector». Unlike European social enterprises, focused on integrating vulnerable groups of population with low economic competitiveness into the labor market, social enterprises in the US are focusing mainly on producing «social products and services») available to consumers at no (or below market) cost.
The formation of institutional conditions for the development of social enterprises in the United States is connected to the extensive system of private support in the form of nongovernmental funds, providing their financial assistance, educational, training and consulting services. Some of them help to create a network of social entrepreneurs («Kellog Foundation», «Kauffman Foundation», «Rockefeller Foundation»), others support social startups («Roberts Enterprise Development Fund»), third raise the level of education and entrepreneurial skills of social entrepreneurs with the help of training programs, scholarships and grants («Skoll Foundation», «Kauffman Foundation»). The largest international fund «Ashoka: Innovators for the Public», established by William Drayton in 1980 is a global association the activity of which is to seek and support entrepreneurial social initiatives and promote them. At the time of creation its annual budget was about 50,000 USD, today it exceeds 85 million USD with investment support from individuals and nongovernmental entities. Fund supports social entrepreneurship programs in more than 60 countries and has over 1,800 alumni [9]. Besides, a number of universities sponsor competitions for the best social innovations and provide financial assistance to the initiators of new social ideas.

However, this does not mean that social enterprises are not supported by state. At the federal level, they are provided with legal preferences for licensing and certification of their organizations, soft loans under government guarantees, grants from the federal budget, etc.

As for the legal regulation of social enterprises, there are no specific laws in the United States regarding their activities. Only in some states social enterprises do operate in two legal forms: a low-profit limited liability company (L3C) and benefit corporation (BC). First enterprise with the L3C-status was established in Vermont in 2008. This status does not provide tax benefits, however helps to obtain budget grants and conclude government contracts. Country's social enterprises are united by the Social Enterprise Alliance (SEA) [10, p. 65].

Thus, American model of social entrepreneurship is on the edge between business structures and nonprofit organizations, and in 
Comparative characteristics of social entrepreneurship models

Table 1

\begin{tabular}{|c|c|c|}
\hline Factors & European (except the United Kingdom) & Anglo-American \\
\hline Period of formation & $1970 s-2000 s$ & $1960 s-1990 s$ \\
\hline Conditions of formation & $\begin{array}{l}\text { The rise of the cooperative movement in } \\
\text { times of social security system crisis and } \\
\text { rising unemployment. }\end{array}$ & $\begin{array}{l}\text { Commercialization of NPOs while reducing } \\
\text { the cost of implementing federal programs } \\
\text { against poverty. }\end{array}$ \\
\hline Organizational and legal forms & $\begin{array}{l}\text { Social cooperatives, social mission } \\
\text { companies, social enterprises for labor } \\
\text { integration (WISE). }\end{array}$ & $\begin{array}{l}\text { Associations, foundations, low-profit } \\
\text { companies, social corporations, private } \\
\text { charities. }\end{array}$ \\
\hline Profit sharing opportunities & $\begin{array}{l}\text { Mainly on implementing social projects and } \\
\text { organization's development. }\end{array}$ & Unlimited (Not restricted) \\
\hline Areas of functioning & Social services market, labor market. & Wide range of nonprofit and private activities. \\
\hline Legal regulation & $\begin{array}{l}\text { Legislative fixing of organizational forms } \\
\text { and activities, elimination of administrative } \\
\text { barriers, infrastructure and financial support. }\end{array}$ & $\begin{array}{l}\text { Providing grants from the federal budget, } \\
\text { granting soft loans under the state guarantees, } \\
\text { sponsoring programs for studying the } \\
\text { efficiency of social entrepreneurship. }\end{array}$ \\
\hline Sources of financing & $\begin{array}{c}\text { Funding received for providing social services } \\
\text { under government contracts, subsidies for } \\
\text { implementing a specific project or program, } \\
\text { sponsor contributions. }\end{array}$ & $\begin{array}{l}\text { Own entrepreneurial activity, financial } \\
\text { support of international funds. }\end{array}$ \\
\hline
\end{tabular}

Source: compiled by the author

European, a third important factor - the state is added to them. Therefore, social entrepreneurship in Europe is considered to be the most institutionalized form of cross-sectorial partnership, by which state, business, and nonprofit organizations find ways to work together, solving issues beyond their direct influence, or require pooling of resources.

The government of Canada in solving social issues relies on an extensive community economic development network (CED). It is an association that operates locally and creates favorable economic opportunities and social conditions for the population, including its vulnerable groups. A law, defining the status of social enterprises as «public benefit societies» was adopted in 2012 only in the Canadian province Nova Scotia. This allows to test their effectiveness at the level of a separate province, before they become universal for the whole country [11, p. 420].

Economic crisis of the 1990s became an impetus for the development of social entrepreneurship in Southeast Asia. Establishing of the first social enterprises took place at the absence of funds and other sources: the only means of starting a business were the personal funds of the entrepreneur or grants from various foundations or religious organizations. In countries where the main religion is Islam, Islamic funds have become a major source for financing so- cial enterprises, investing in those, that comply with the principles of Sharia law, i.e. not related to producing alcohol, chemicals, tobacco, gambling, brokerage or advertising.

One of the first Asian countries to create conditions for development and financial support program for SE was India. There are at least three major federal funding sources for social enterprises today: 1) Agricultural Technology Development Council (CAPART), which works under the Ministry of Agriculture and provides funds for rural development; 2) Small Business Development Bank (SIDBI), founded to finance micro-enterprises that contribute to creating job opportunities and balanced regional development; 3) National Innovation Fund (NFI), which provides organizational and infrastructure support for eco-innovations. The $\mathrm{Na}$ tional Innovation Council also plays an important role in this context, as it supports innovative projects in the social sphere [12, p. 59].

South Korea has the most structured support for social entrepreneurship. Its government's «Social Vision 2030» program, adopted in 2006, involved 11 ministries, major Korean corporations and a large number of nonprofit organizations, views social enterprises as an effective tool for providing social services. Social enterprises there receive benefits from the state in the form of exclusive rights to sell products and services 
to the government agencies. Generally, Korean strategy is aimed at creating economically sustainable, market open organizations, capable of solving social issues [13, p. 72].

Similar programs for social entrepreneurship financial support are developed in Thailand, Indonesia and Japan. Singapore has launched the «Impact Investment Exchange» - a platform for attracting investments in social businesses. To operate on it, there needs to be a strategy for achieving concrete results and sponsor compliance with an investment transparency [14, p. 170].

A significant event for the development of social entrepreneurship was founding by Professor Muhammad Yunus a micro-credit organization, called "Grameen Bank», which provided group loans without collateral to the Bangladeshi population (mainly women whose earnings were less than 2 USD per day) for establishing microbusiness. Later, micro-insurance, micro-investments and other services emerged in this area, which began to actively develop around the globe as an effective sociallyoriented business. Awarding M. Yunus with the Nobel Prize in 2006 has had a significant popularizing effect on the development of social entrepreneurship, aimed at fighting poverty in Asia, Latin America and Africa [15, p. 93].

However, the results of social entrepreneurial activities in South Asia are far from the scale of the region's social problems. To certain extent, it happens due to the lack of funding. Most of small social enterprises in South Asia are out of sight of society and cannot attract significant government and donor support.

The main drivers for social entrepreneurship development in Latin America have become economic crises and failed state reforms. As a new form of interaction with socially vulnerable groups of population, social entrepreneurship is only at the process of formation. Its activities are to provide services and goods to low-income groups of society and to include them in the production process. The issues of discrimination and access of the population to healthcare and education services have become areas where social entrepreneurs not only create social value but also obtain economic results.

In most of Latin American countries, legislative system supports social enterprises by pro- viding them a range of tax and credit benefits. However, the rules of providing privilege are developed by public authorities as an urgent response to those problems that require immediate resolution, therefore, they lack of consistency, which complicates their further practical implementation. Despite this, the region is gradually creating a more favorable environment for the development of social enterprises through forming the private investment capital and the activities of various international foundations and associations. («Ashoka», «Center for Social Entrepreneurship», etc.), that provide them educational and consulting assistance, and financial support [12, p. 62].

On the African continent, the most pressing social problems are related to poverty, social inequality and environmental pollution. However, governments in a number of countries consider social entrepreneurship to be «inherently risky» and their actions - «thoughtless». The situation is further complicated by the fact that certain states restrict the freedom of socially oriented organizations' activity. [16, p. 348]. FATE Foundation (2000) and Lagos Digital Village (2004), formed from non-profit organizations, have become the first social entrepreneurial firms in the African region. Active educational and investment work of international associations («Ashoka», «Schwab Foundation») for supporting the social entrepreneurs has a positive impact on the development of an appropriate environment and forming the institutional framework of social entrepreneurship in Africa $[17$, p. 5]. Considering that a huge layer of social issues remains out of the reach of states and the private sector, social entrepreneurship could become a driving force, not only capable of contributing to the solution of the specific social problems, but may also initiate social transformations in them.

Conclusions and suggestions. Summarizing all the above mentioned, it should be noted that social entrepreneurship is a global phenomenon, which, on the one hand, is actively spreading across the globe and, on the other has its national forms and features, depending on the degree of development of relevant institutions, traditions and culture. Conducted analysis made it possible to conclude that social 
entrepreneurship is much more active and diverse in the developed industrial countries, than in those of the third world, and more consistently implemented in start-up organizations under the supervision of business structures, rather than as a result of a traditional nonprofit organization's evolution.

Social entrepreneurship is a relatively new phenomenon for Ukraine, but organizations that are actually implementing its principles in their daily activities are already emerging. Besides, national scientists are working on options for its institutional development. The analysis of developed industrialized countries' experience and trends in its development on the global scale may become the basis for further research, development and implementation of the investment projects that will facilitate social entrepreneurship within national conditions.

\section{References:}

1. Austin. J, Stevenson H., Wei-Skillern J. Social or commercial entrepreneurship: Same, different, or both? Entrepreneurship: Theory and Practice. 2006 . Vol. 30 (1). P. 1-22.

2. Christie, M.J., Honing, B. Social entrepreneurship: new research findings. Journal of World Business. 2006. Vol. 41. P. 1-5.

3. Mair J., Marti I. Social entrepreneurship research: A source of explanation, prediction, and delight. Journal of World Business. 2006. Vol. 41, No. 1. P. 6-44.

4. Ries Eric. The Lean Startup. How Today's Entrepreneurs Use Continuous Innovation to Create Radically Successful Businesses. 2011. Crown Business. 320 p.
5. Kerlin, J. Social enterprise in the United States and Europe: understanding and learning from the differences. Voluntas. 2006. N 17. P. 246-262.

6. Defourny J., Nyssens M. Conceptions of social enterprise and social entrepreneurship in Europe and the United States: convergences and divergences / Journal of Social Entrepreneurship. 2010. Vol. 1, Is. 1. P. 32-53.

7. A Map of Social Enterprises and Their Ecosystems in Europe. European Commission. A Report Submitted by ICF Consulting Services. Wilkinson, James Medhurst, eds. 2015. 141 p.

8. Alter K. Social enterprise typology. Virtue Ventures LLC. 2007. $124 \mathrm{p}$.

9. Ashoka Organization. What is a social entrepreneur? Ashoka: Innovators for the Public. URL: http://www.ashoka.org/ social entrepreneur (date of access: 19.01.2020).

10. Kerlin, J. A. Social enterprise: a global comparison. Tufs University Press. 2009. 211 p.

11. Thompson J. The world of the social entrepreneur. International Journal of Public Sector Management. 2002. Vol. 15, Issue 5. P. 412-431.

12. Mair J., Schoen O. Successful social entrepreneurial business models in the context of developing economies : an explorative study. International Journal of Emerging Markets. 2007. Vol. 2, Issue 1. P. 54-68.

13. Santos J, Macatangay L., Burns C. Southeast Asia: Social Enterprise a Global Comparison 2009. Tufts University Press. 2009. P. 64-87.

14. Dacanay, M., Robinson J., Mair J. Social Entrepreneurship: An Asian Perspective. International Perspectives on Social Entrepreneurship. 2009. P. 163-182.

15. Defourny J., Kim S.-Y. Emerging Models of Social Enterprise in Eastern Asia: a Cross-Country Anaysis. Social Enterprise Journal. 2011. Vol. 7. No 1. P. 86-111.

16. Urban, B. Social entrepreneurship in South Africa. International Journal of Entrepreneurial Behavior \& Research. 2008. Vol.14. Issue 5. P. 346-364.

17. Sesan, G. Social enterprise in Africa: an emerging concept in an emerging economy. International NGO Journal. 2006. Vol.1. Issue 1. P. 4-8. 
Аннотация. В статье отражены особенности социального предпринимательства в качестве механизма взаимодействия социальных ценностей и инновационных бизнес-технологий, направленного на нивелирование проблем социально незащищенных категорий населения в условиях неспособности общества эффективно решать их традиционными методами рыночной экономики и государственной поддержки. Рассмотрено функционирование социального предпринимательства не только в развитых североамериканских и европейских странах, где оно уже имеет сложившуюся традицию, но и в тех, где только начинает зарождаться (странах Латинской Америки, Юго-Восточной Азии и Африки). На основе сравнительного анализа регионального развития социального предпринимательства продемонстрированы различия между американской и европейской моделями. Установлено, что развитие социального предпринимательства зависит не только от существующей институциональной среды, но и от национальных условий, в которых формируется данный вид деятельности. Исследованы особенности правового обеспечения и государственной поддержки социального предпринимательства в различных регионах мира, определены факторы, влияющие на его распространение и растущую популярность.

Ключевые слова: социальное предпринимательство, американская и европейская модели, социальные инновации, организационно-правовые формы, инвестиционные фонды.

Анотація. У статті висвітлено особливості соціального підприємництва як механізму взаємодії соціальних цінностей та інноваційних бізнес-технологій, спрямованого на нівелювання проблем соціально незахищених категорій населення в умовах неспроможності суспільства ефективно вирішувати їх традиційними способами ринкової економіки та державної підтримки. Розглянуто функціонування соціального підприємництва не тільки в розвинених північноамериканських і європейських країнах, де воно вже має сформовану традицію, а й у тих, де тільки починає зароджуватися (країнах Латинської Америки, Південно-Східної Азії та Африки). На основі порівняльного аналізу регіонального розвитку соціального підприємництва продемонстровано відмінності між американською й європейською моделями. Встановлено, що розвиток соціального підприємництва залежить не тільки від діючого інституційного середовища, а й від національних умов, в яких формується даний вид діяльності. Досліджено особливості правового забезпечення та державної підтримки соціального підприємництва у різних регіонах світу, визначено чинники поширення його практик. Проведений аналіз свідчить, що в розвиненому індустріальному суспільстві соціальне підприємництво розвивається набагато активніше і різноманітніше, ніж в країнах третього світу, а також більш послідовно реалізується у новостворених організаціях під патронажем бізнес структур, ніж у результаті самостійної еволюції традиційної некомерційної організації. Для України соціальне підприємництво $\epsilon$ відносно новим явищем, але організації, які фактично впроваджують його принципи у свою повсякденну діяльність, вже з'являються. Крім того, національні вчені працюють над варіантами його інституційного розвитку. Аналіз досвіду розвинених промислово розвинених країн і тенденцій його розвитку в глобальному масштабі може стати основою для подальших досліджень, розроблення і реалізації інвестиційних проєктів, які сприятимуть соціальному підприємництву в національних умовах. Виходячи 3 того, що величезний пласт соціальних проблем залишається поза увагою держави і приватного сектору, саме соціальне підприємництво може стати тією рушійною силою, яка сприятиме вирішенню конкретних соціальних завдань суспільства.

Ключові слова: соціальне підприємництво, американська й європейська моделі, соціальні інновації, організаційно-правові форми, інвестиційні фонди. 